\section{Chapter}

\title{
Impact and assessment of climate change on biological diversity
}

\author{
Mahrukh and Rohitashw Kumar* \\ College of Agricultural Engineering and Technology, SKUAST- Kashmir \\ Shalimar Campus, Srinagar, India
}

\begin{abstract}
Global climate change has both direct and indirect effects on the biological and physical contexts of biodiversity. Climate change's consequences include increased temperature and precipitation, high salinity, and intense climate conditions such as hurricanes, cyclones, and droughts, all of which have a significant negative impact on habitats and on the structure and functioning of the environment and ecosystems. Investigating the impact of climate change on biodiversity is difficult because changes occur steadily over time and the consequences are interactive with other environmental problems. In the previous two decades, there has been an increase in the number of endangered species, including plants, fish, amphibians, molluscs, birds, mammals, insects, and reptiles, among many other species. This chapter's major goal is to focus on biodiversity and the impact of global warming and climate change on terrestrial and aquatic ecosystems, as well as on the agriculture and human existence. Furthermore, numerous tools and methods for analysing the effects of climate change using diverse techniques, as well as potential mitigation measures for conserving biodiversity from climate change's consequences, have been discussed.
\end{abstract}

Keywords

Biodiversity, Climate change, Ecological models, Mitigation, Range shift

$\square$ Rohitashw Kumar, Email: rohituhf@rediffmail.com ( ${ }^{*}$ Corresponding author)

(C) 2021 | Agro Environ Media | Agriculture and Environmental Science Academy, Haridwar, India 


\section{Introduction}

According to the International Union for Conservation of Nature (IUCN), biodiversity is "the heterogeneity of life forms from all types of habitats and ecological complexes" (IUCN, 2010). There are between 5 to 30 million distinct species on Earth; the majority are microbes, with just approximately 1.75 million accurately recognised (IUCN, 2000). The interactions of all the elements that comprise the world's total biodiversity, considered as a whole, create the foundation upon which human civilization has evolved. Biodiversity loss is one of the most critical environmental issues, given how much it contributes to the world economy and human health (Martens and Rotmans, 2005). There has been a steady decline in species richness since 1970, according to the Living Planet Index. By 2020, it is anticipated that species populations would decline by 67 percent. In the previous two decades, there has been an increase in the number of endangered species, including plants, fish, amphibians, molluscs, birds, mammals, insects, and reptiles, among many other species. A ten-year period between 2006 and 2015 saw a loss of biodiversity in reptiles, molluscs, and fish, with average losses of $12.5 \%$ and $8.5 \%$, respectively. World Wildlife Fund (WWF) (2016) attributes the decline in biodiversity to a variety of factors including habitat destruction and degradation, resource exploitation, unsustainable agriculture, fishing, climate change, and ecosystem pollution. Climate change will become one of the world's primary causes of biodiversity loss in the future, and there are compelling reasons to believe that climate change will result in the extinction of a number of taxonomic specie as well (Sala et al., 2000). The IPCC's 4th Assessment Report (AR4) affirmed that climate change is having a significant impact on many aspects of biodiversity. These implications will also have an impact on the ecosystem, the genetic diversity of animals, and ecological relationships. These effects have far-reaching implications for the natural world's long-term existence as well as the numerous benefits and resources that people derive from it.

Climate change, as one of the most important factors influencing organism growth and species densities, has the ability to affect the structure of plant and soil ecosystems, as well as their interactions. A steady increase in the average temperature of the Earth's atmosphere and seas is referred to as climate change. Climate change is one of the most significant factors influencing disaster risk, according to the Intergovernmental Panel on Climate Change (IPCC) (IPCC, 2013). According to the Intergovernmental Panel on Climate Change (IPCC), global warming will continue to climb by $5.8^{\circ} \mathrm{C}$ by 2100, compared to $1.4^{\circ} \mathrm{C}$ in 1990 (IPCC, 2007).As a result of climate change, there may be a range of environmental and biological consequences (Lama and Devkota, 2009). The fast-growing trend toward warming has already had obvious and typically negative consequences on important resources, such as soil, living organisms, and water, during the previous few decades (Danovaro et al., 2004). Climate change, together with biodiversity loss, is a major issue on the environmental, social, cultural, and political fronts (Rosales, 2008). Further temperature rises of up to $3^{\circ} \mathrm{C}$, according to the IPCC, will almost likely produce substantial changes in the composition and operation of all ecosystems, as well as an increased chance of animal extinction. The findings show that climate change will have an impact on biodiversity, among other things, by altering lifecycles, developing new physical features, shifting 
habitat and species distribution, and increasing the frequency and severity of pest and disease events (Hui, 2013; Sintayehu, 2018). Figure 1 illustrates the impact of climate change on biodiversity. Global warming will have an impact on forest species, both through habitat shifts and in direct reaction to temperature rises, precipitation variations, and severe weather events (Sarkar, 2012). Species extinction and relocation cycles have been triggered all over the world as a result of climate change. According to current climate projections, further environmental change will occur in the next decades (IPCC, 2013). Due to stresses and biological behaviours, climate change is also thought to be a significant driver of habitat alteration and degradation.

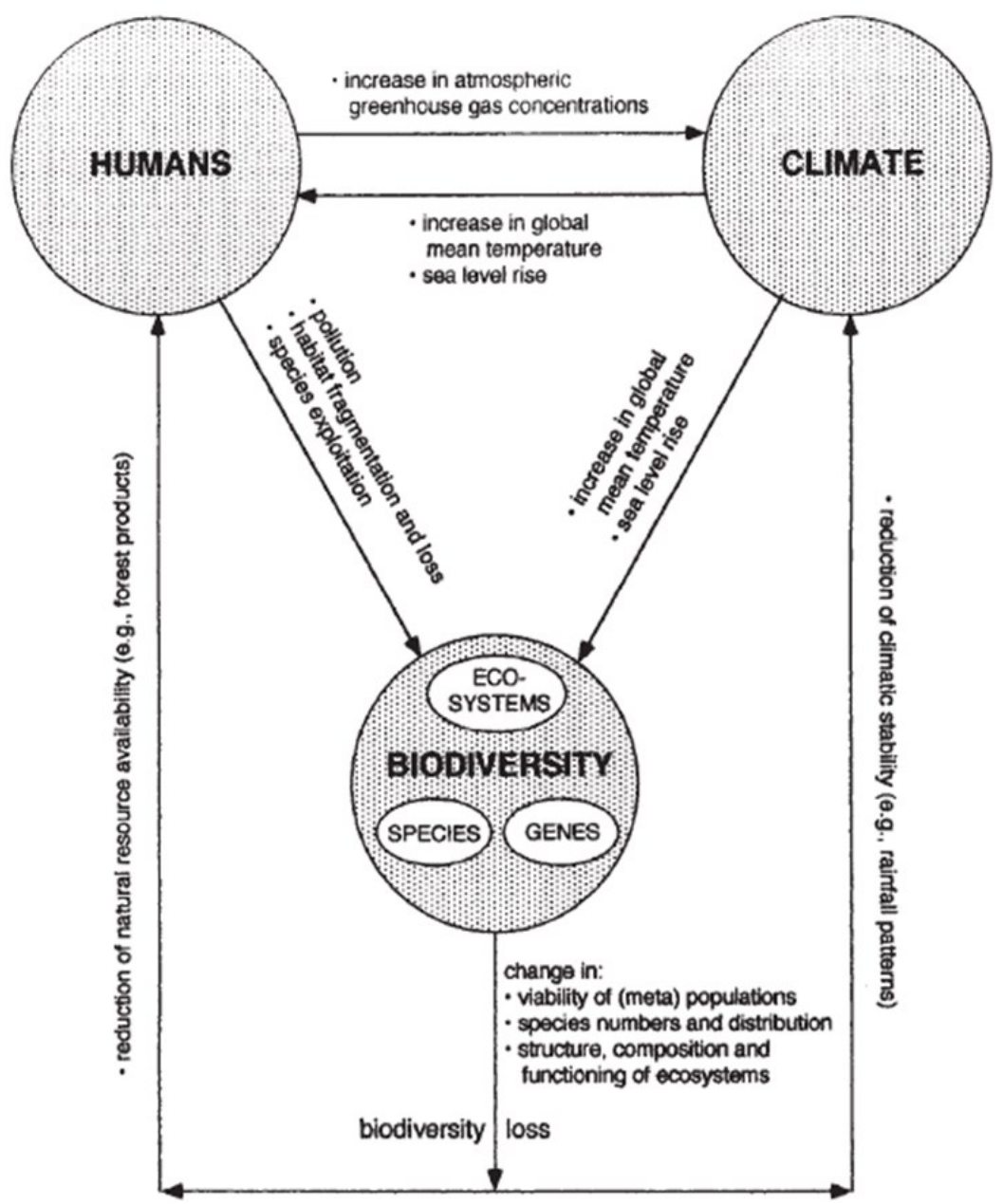

Figure 1. Effect of climate change and human interference on biodiversity (Adapted from Kappelle et al., 1999). 


\section{Effect of climate change on biodiversity}

Biodiversity and ecosystem services based on biodiversity are climate-sensitive by definition. As the temperature rises and the planet warms, regional circumstances are impacted in a variety of ways. As the climate continues to change, there appears to be an impact on biodiversity loss. As a result of such effects, the composition and distribution trend of ecosystems and ecological services (Figure 2), on which human civilizations rely, are altered. Warmer temperatures cause greater evaporation, resulting in more rain and snowfall. The increased precipitation, on the other hand, is distributed unevenly, resulting in greater rainfall in some regions and dryness in others. Portions of South and Southeast Asia are experiencing heavy monsoon rains and sea level rise, while parts of southern Africa and the American Southwest are experiencing catastrophic droughts and crop failures. Dense snowstorms, hurricanes that are substantially larger, more violent heat waves, and intense rainstorms with accompanying flash flooding are all becoming more prevalent across the world (IFAW, 2013). Reduced snowfall and decreasing glaciers in the mountains result in less melted snow flowing into rivers, streams, and lakes for fish and animals, as well as less water accessible for drinking and agriculture (Palita, 2016).

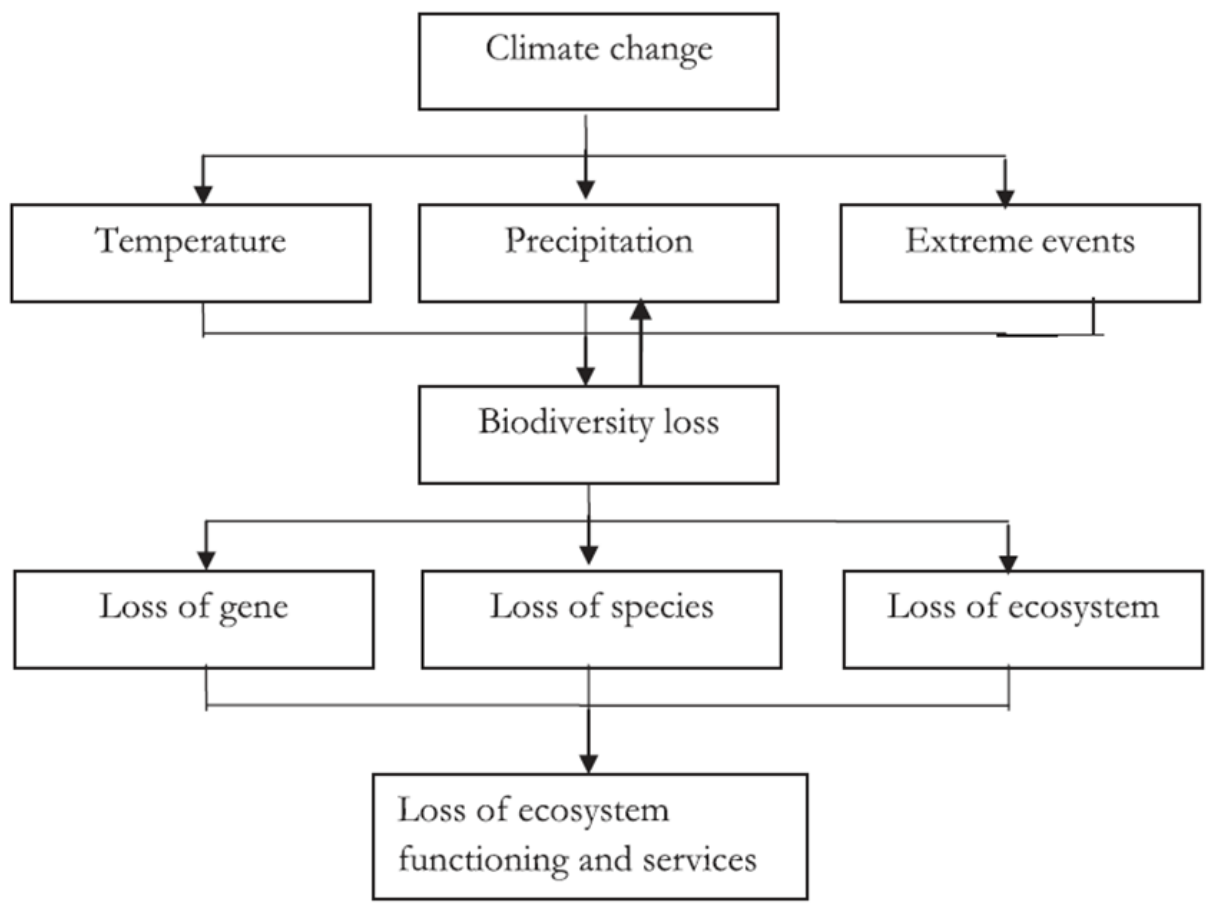

Figure 2. Impact of climate change on biodiversity and ecosystem loss (Adapted from Sintayehu, 2018). 
Due to disturbance and competition from invasive species, species migration is presently on the rise and is likely to continue to have an influence on aquatic, land-based, and freshwater ecosystems (Wernberg et al., 2011). Many creatures, including the blue whale (Balaenoptera musculus), polar bear (ursus maritimus), great white shark (Carcharodon carcharias), ringed seals (pusahispida), and others, would begin to decrease and finally perish due to a lack of food and crucial alterations in sea-ice ecosystem interactions. Environmental changes such as change in temperature causes life forms to respond physiologically by following an optimal curve in which productivity (e.g., metabolic rate such as photosynthetic activity, rate of growth) is maximised under ideal conditions and survival is limited to a specific temperature range. Increased metabolic rates are considered to be caused by a drop in temperature below the minimum. Physiological rates (enzyme response, respiratory rate, food absorption, production, and growth) increase as a result, with the slope of the rise varying per organism. This physiological reaction can change phenology, which refers to all life-cycle activities that take place over time, such as larval development, hibernation season, migration to winter or summer habitats, and so on. Increases in metabolic rates are linked to increases in nutritional requirements, which means certain animals may need to eat more food or prey to fulfil their increased energy needs. As a result, if competing species display significant variations in competitive adaptation over a temperature gradient, competitive supremacy will shift along a small temperature differential.

\section{Effect on terrestrial life}

Animal and bird populations are declining as a result of changes in the environment and the eco-system. 150 bird species have already gone extinct in the previous 500 years, and one out of every eight species is currently endangered (Mooney et al., 2009). Any animal's initial response to a changing climate is to relocate in order to preserve ideal climatic circumstances, a process known as range shifts. At the colder poles, species are shifting polewards, whereas range boundaries are shrinking at the hotter range border, where temperatures are no longer viable. Land-based species are moving to higher elevations, where the temperature is cooler. Warming temperatures harm heat-sensitive plants (Welbergen et al., 2008), resulting in an increase in thermophilic species concentration (Reid, 2006) and shifts in species diversity trends (Roder et al., 2010). Warmer winters and higher seasonal heat levels, for example, are thought to have contributed to the mountain pine beetle (Dendroctonus ponderosae) epidemic's extreme severity and size in British Columbia's pine forests (Carroll et al., 2004). Because different species react at differing rates and to variable degrees, fundamental relationships between species are frequently disrupted, and new interactions develop. These anomalies will result in the development of new biotic species and significant changes in ecosystem functioning, with far-reaching and often unanticipated consequences for both ecological and human populations.

As a result of increased temperature in various areas, changes in the distribution of numerous animals have been detected. Warmer temperatures, for example, have resulted in an upslope shift in alpine bird habitat in Italy. Several habitats are anticipated to merge with ski-industry-friendly locations, creating conservation challenges for several bird species (Brambilla et al., 2016). Climate change has also affected 
the northward and altitudinal movement of bark beetles in North America. Increased temperatures and droughts make trees more susceptible to defoliators and bark beetles, increasing the intensity of pest infestations, which might have an impact on the ecosystem by increasing fuel loads and fire occurrence at high latitudes (Cudmore et al., 2010). Climate change alters the location, pattern, and density of terrestrial vegetation, resulting in higher average temperatures and a longer growth season. Changes in vegetation exacerbate climate change by influencing albedo, biomass, and evapotranspiration (Pearson et al., 2013). Drought and forest fire vulnerability may also increase as a result of climate change. In the future, it is predicted that tropical and semi-tropical forests and grasslands, which are rich in biodiversity and provide water management, carbon sequestration, nourishment, and timber, among other ecosystem services, would be converted at a faster rate (Harley et al., 2006). Over a 30-year period, spring leaf unfolding and fruit maturation patterns changed by 2.5 and 2.4 days every decade, respectively (Mooney et al., 2009).

\section{Effect on aquatic life}

Ocean acidification and temperature increases, more frequent and severe weather events, and changes in oxygen levels or deoxygenation procedures are some of the most immediate impacts of global warming on the marine ecology (IPCC, 2007). Nitrogen deposition, warming, precipitation variations, and changed runoff patterns are all major threats to freshwater systems worldwide (Woodward et al., 2010). Global warming has had a substantial influence on marine ecosystems, resulting in habitat loss and the introduction of invasive plant and animal species, as well as increased heat, acidity, pollution, and massive nutrient runoff into water (Mooney et al., 2009).Climate change poses the greatest danger to corals, sea grass, mangroves, salt marsh grasses, and oysters, which provide habitat for hundreds of other marine species (Harley et al., 2006). Coral reef biodiversity has already suffered as a result of rising water temperatures (Leahy, 2007). Increasing temperatures may affect changes in the structure of different plankton functional groups (Polovina and Woodworth, 2012).Climate change and weather patterns, according to a study conducted by Jackson (2008) in coastal estuaries, have resulted in the loss of 80 percent of the largest species, such as sharks and blue whales, 90 percent of oysters, 65 percent of sea grass, and 67 percent of wetlands. According to numerous studies, global warming causes organisms to alter their ranges in the ocean, with cooler water at deeper depths. Turan et al. (2016) utilised purse seiner, trawler, and trammel nets to examine surface water temperature change, as well as the composition and distribution of biodiversity, throughout Turkey's Mediterranean, Marmara, and Black Sea coasts for 41 years. Researchers found that surface sea water temperatures have risen by 1.5 to $3{ }^{\circ} \mathrm{C}$ in all seas, compelling native species to live with alien species. A total of 74 alien fish species have been discovered in Turkish waters (Figure 3). Demersal fish in the North Sea have migrated deeper as temperatures has increased. Smaller, less abundant southern species have migrated southwards, whereas thermally specialised fish have moved northwards (Dulvy et al., 2008). In response to rising water temperatures in Finland, the northern pike expanded its territory, whereas Atlantic salmon, an anadromous cold-water fish, dropped in number. 


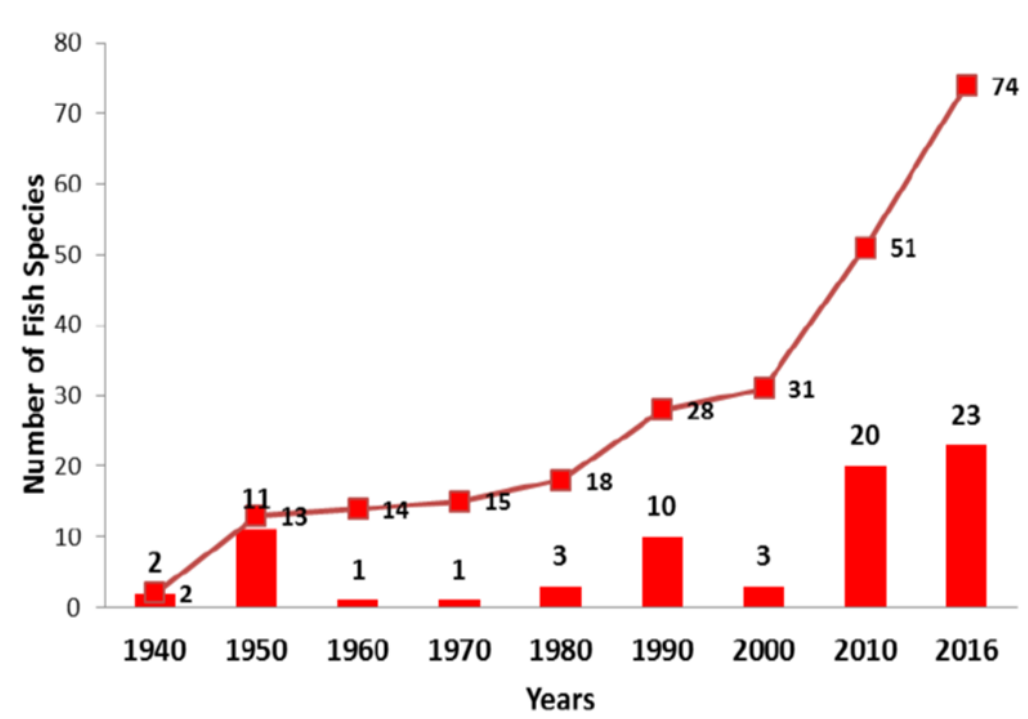

Figure 3. Graph indicating trend of alien species of fishes in waters of Turkey (Adapted from Turan et al., 2016).

\section{Effect of climate change on agriculture}

Temperature, sunlight, and water are the major regulators of agricultural development; therefore, climate change has a direct influence on agriculture. While certain aspects of climate change, such as a longer growing season and warmer temperatures, may help agriculture flourish and produce more, others, such as reduced water availability and more frequent severe weather events, may have negative repercussions. Climate change has an impact on plant development and productivity by increasing unpredictability in rainfall patterns, heat stress, pest and disease invasion, and crop cycle shortening. The influence of climate change on agriculture is predicted to cause havoc on certain parts of agricultural systems while also presenting possibilities for development. Shifts in the average climate away from present conditions may need changes to current practises to maintain production, and the optimal cropping strategy may need to be altered in some situations. Agricultural production, farm revenue, and food security may all be affected by raised temperatures during the vegetative season (Battisti and Naylor, 2009).

Varying plants have different temperature sensitivity. Crop adaptability and production are projected to grow and spread northward in the mid- and high-latitudes, particularly in cereals and cold-season seed crops (Maracchiet al., 2005; Tuck et al., 2006; Olesen et al., 2007). It was predicted by the IPCC (2001) that wheat yields will decline by $5-10 \%$ for every $1^{\circ} \mathrm{C}$ drop in temperature, and also that South Asian agricultural production might plunge by 30 percent by the twenty-first century. India's agricultural productivity is expected to drop by $40 \%$ by 2080 . Temperature rises, according to the 
Intergovernmental Panel on Climate Change (IPCC), will destabilise wheat-growing countries, putting hundreds of millions of people on the edge of famine (IPCC, 2007). A small change in average annual rainfall might have a big impact on a region's output. The monsoon rainfall pattern, both geographically and temporally, is critical for Indian agriculture (Kumar et al., 2004). Asada and Matsumoto (2009) looked at the relationship between district-level crop output statistics (rainy season 'kharif' rice) and precipitation from 1960 to 2000.In a number of scenarios, different locations were shown to be sensitive to precipitation extremes. Crop productivity in the upper Ganges basin is linked to total precipitation throughout the relatively short growing season, rendering it sensitive to drought. The lower Ganges basin, on the other hand, was susceptible to pluvial floods, but the Brahmaputra basin saw an increasing impact of precipitation fluctuation on crop production, particularly during drought. Climate change has a direct impact on crop evapotranspiration (ET). Rising temperatures in Rajasthan's arid areas are projected to result in a 14.8\% increase in overall ET consumption (Goyal, 2004). According to the study, even a slight increase in ET demand due to global warming will have a bigger impact on Rajasthan's dry zone ecology's vulnerable water supplies (Goyal, 2004). As a result, climate change will affect soil moisture, groundwater recharge, the frequency of floods and droughts, and, eventually, the water table at various locations (Huntington, 2003; Eckhardt and Ulbrich, 2003; Allen et al., 2004).

\section{Assessment of climate change impact on biodiversity}

When it comes to dealing with global climate change, the most pertinent concern is quantifying biodiversity potential. Nunez et al. (2019) conducted a meta-analysis of studies that used bioclimatic models and climate-change scenarios to quantify the sensitivity of terrestrial ecosystems to climate change, including global mean temperature increases of up to $6^{\circ} \mathrm{C}$ by 2100 , along with related climate variables like precipitation change above pre-industrial levels. Two efficacy measures for measuring biodiversity changes were created using the data of 97 research. These metrics are the fraction remaining species (FRS) and the fraction of remaining area (FRA) with the appropriate climate for every single species. At moderate temperature levels (e.g., $1-2{ }^{\circ} \mathrm{C}$ ), the study found that species cannot disperse or adapt, and that a significant decrease in their original biodiversity is predicted. Following the predicted climatic change, FRS is calculated as the average of ratios between the residual species number and the initial species number in each part of the map of the research region.

$$
F R S=\frac{1}{n} \sum_{i=1}^{n} \frac{S_{d i}}{S_{o i}}
$$

Where,

$\mathrm{S}_{\mathrm{di}}=$ Expected number of species remaining in grid cells i following climate change

$\mathrm{S}_{\mathrm{oi}}=$ number of species in grid cell i during initial condition

$\mathrm{n}=$ total number of grid cells.

FRS is a relative index that ranges from 0 to 1 , with 0 indicating no original species and 1 indicating all 
original species are present. FRS decreases when the climate in one of the grid cells within the study region becomes unsuitable for a species. FRS depicts species' reactions to climate change on a local level. FRA calculated as the ratio between the appropriate original and surviving climatic area is computed for each species.

$$
F R A=\frac{1}{S} \sum_{J=1}^{S} \frac{A_{d i}}{A_{o i}}
$$

Where,

$\mathrm{A}_{\mathrm{dj}}=$ remaining suitable climate area for species $\mathrm{j}$ after climate change

$\mathrm{A}_{\mathrm{oj}}=$ climate area for species $\mathrm{j}$ in original situation before climate change

$S=$ number of species

FRA is also a relative index that ranges from 0 i.e., no initial appropriate climate area to 1 i.e., unchanged climate area.

Another study conducted by Habibullah et al. (2019) employed the improved threatened speciesclimate change equation to experimentally analyse the impact of climate change on the number of threatened species:

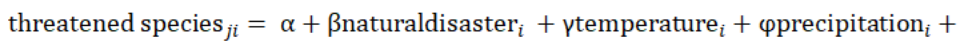

$$
\begin{aligned}
& \delta_{\text {realGDP }}+\text {-government effectiveness }_{i}+\epsilon_{\mathrm{ji}}
\end{aligned}
$$

where $\beta, \gamma, \phi, \delta$, and $\theta$ are the parameters coefficients to be estimated and final term indicates the error. Although there are other methods for deriving conclusions, such as existing palaeontological or existing data, experiments, observations, and meta-analyses (Lepetz et al., 2009), ecological modelling is the most commonly used methodology for predictive research. According to Crick (2004), despite the fact that many bioclimatic models are very accurate (Williams et al., 2003) the majority of research into the effects of climate change on organisms still rely on predictive large-scale models to cope with abiotic data from satellite sensors. There are three fundamental approaches for estimating biodiversity loss: future changes in species range or extinction, future changes in species diversity, and future changes in species diversity. Furthermore, all three modelling approaches have mostly focused on one axis of response (space change), disregarding the importance of the other components (Bellard et al., 2012). Existing species ranges are linked to a number of climatic variables using Bioclimatic Envelope Models, which define each species' climatic niche (envelope). The niche may then be forecast for various future temperature scenarios to determine the species' suitable climatic space's possible redistribution. Considering species-area relationships (Thomas et al., 2004) or IUCN status, the likelihood of extinction may then be evaluated using a number of approaches (Thuiller et al., 2005). Models of Dynamic Vegetation (DVM) anticipate changes in vegetation and associated biogeochemical and hydrological cycles in response to climate change. DVMs use time series of meteorological data (e.g., temperature, precipitation, humidity, sunshine days) and topography and soil characteristics to mimic monthly or daily dynamics of biological processes.DVMs are currently of limited use for directly projecting biodiversity variations, but when combined with extinction models, they give an estimate of the risk of extinction of species on a regional or worldwide scale (Van Vuuren et al., 2006). The species-area 
relationship (SAR) is an empirical correlation seen between a species' population and its area (Thomas et al., 2004). Extinction risk is calculated by observing that extinction risk increases with decreasing range and population size as a direct result of habitat loss or climate-induced area shrinkage. SAR methods may underestimate or exaggerate the threat of extinction based on species' capacity to survive in low populations or adapt to new environments, and they may also be unable to define a timeline for extinctions (Chevin et al., 2010). DRR (dose-response relationship) models can generate empirical correlations between the relative significance of global variables and changes in species decline using observable data and experiments. The most common use of species distribution modelling (SDM) has been to anticipate the impact of climate change on the global distribution of one or more species at a time (Thuiller, 2003).Such predictions may be useful in developing conservation strategies for species of critical concern, but they are less applicable to overall biodiversity planning. SDM is a powerful method for spatially anticipating the explicit impact of climate change on biodiversity.

Innovative concepts and techniques must be developed in order to adapted successful mitigation and remediation solutions on a medium and small scale. Sound is one of the most intriguing alternatives since it is an important route for intraspecific and interspecific communication across hetero- and homoeothermic groups of animals. The study of sound from an ecological standpoint is known as eco-acoustics (Sueur and Farina, 2015). Eco-acoustics has been widely used in biodiversity assessments, such as habitat assessment (Bormpoudaki et al., 2013), habitat quality variations (Piercy et al., 2014), habitat selection (Figueira et al., 2015), distribution and dynamics (Risch et al., 2014), population density (Lucas et al., 2015), and species invasion (Both and Grant, 2012). Eco-acoustics and related sub-disciplines are critical subjects of study and application for the complex issues raised by climate change. When coupled with other remote sensing methods, the expansion of eco-acoustic approaches provides a powerful new methodology for exposing behaviour of species and environmental systems in the context of climate change (Krause and Farina, 2016).

\section{Impact on human life}

As a result of climate change, temperatures rise, ice melts, and severe other weather events become more prevalent. Water-borne diseases like cholera and typhoid, tropical and vector-borne diseases like malaria, dengue fever, and plague, as well as rodent-borne diseases such as plague, are caused by extreme events like floods, droughts, and storms that force people to flee from their homes. Temperature changes have caused an upslope shift in malaria distributions in Ethiopia and western Colombia, resulting in an increase of average malaria cases in warmer years. Previously malaria-free high-elevation regions in Ethiopia are now within the disease's viable range. Similarly, in Colombia, temperatures fluctuated without a consistent warming trend, and high-altitude malaria incidence shifted drastically in response to temperature changes (Siraj et al., 2014). Another example is the outbreak of Vibrio, a bacterial aquatic disease, across northern Europe. Changes in sea surface temperature are a source of concern in the Baltic (Baker-Austin et al, 2013). The rising sea level has already swamped a number of islands, and millions more migrants throughout the world will soon be 
in need of refuge. Saltwater entering fresh water sources has polluted the land and may soon impose a food safety concern.

\section{Mitigation measures}

Biodiversity is affected by climate change through changes in distribution, species mobility, invasions of alien species and phenological shifts, such as in breeding periods, migration seasons, etc. Even small climate changes might cause the extinction of a few vulnerable or sensitive species. In the face of climate change, the only way to prevent environmental degradation is to reduce human pressure. Clearly, greenhouse gas emissions must be drastically cut and biodiversity loss must be prevented. Understanding how plants, animals, and organic matter interact is essential for preserving the ecosystem's balance and promoting conservation and preservation of the environment through the establishment of biosphere reserves, increased afforestation and reforestation, and enhanced agro-forestry. The taxation of carbon emissions and/or subsidies on emissions that favour renewable energy sources are two additional important actions to reduce the use of fossil fuels or to boost sink absorption (Omann et al., 2009). Aside from that, there are also legal provisions for voluntary agreements and technological standards, as well as support for improving energy efficiency and road pricing (IPCC, 2007). Strategies for mitigating greenhouse gas (GHG) air concentrations help to stabilise or reduce GHG air concentrations to safe levels for the climate system (Kimmel, 2009). Diversity-focused adaptation and mitigation approaches improve ecosystem security while reducing the impact on natural and human ecosystems. The integration of biodiversity and ecosystem services into an overall adaptive strategy may bring cost-effectiveness and co-benefits in social, economic, and cultural aspects, as well as make substantial contributions to the protection of biodiversity and ecosystem services. Additionally, conservation of biodiversity might be used to counteract the detrimental impacts of climate change on biodiversity, while simultaneously enhancing ecosystem function. The beneficial impacts of biodiversity may be employed in forest management strategies to reduce the negative effects of climate change on ecosystem functioning, or to improve the positive effects of climate change on ecosystem functioning (Figure 4). Although the rates and severity of climate change are becoming increasingly difficult for natural adjustment, management and conservation strategies that maintain and recover biodiversity may be expected to mitigate some negative impacts from climate change.

\section{Conclusion}

This decade's environmental worries have centred on climate change, therefore it's imperative that people become aware of the problem and take action. When it comes to species occurrence and variety, even a modest and moderate warming would have complicated consequences, including disturbing ecological functions. There is a rapid increase in emissions of greenhouse gases, which have a negative 


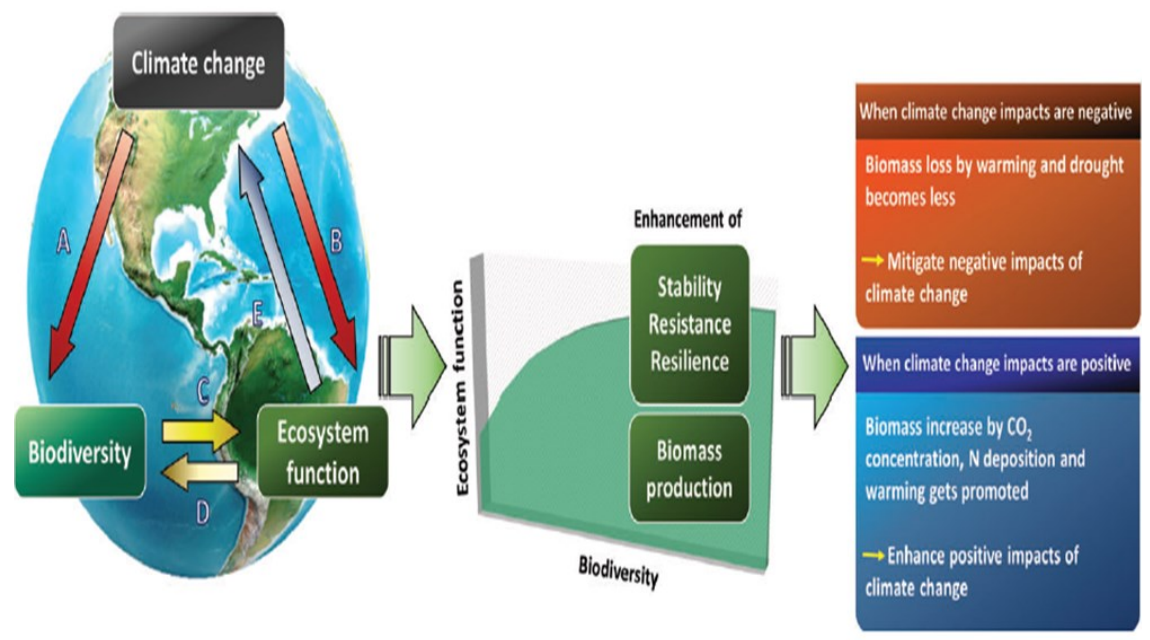

Figure 4. Diagram depicting negative and positive effects of biodiversity change on climate change (Adapted from Hisano et al., 2018).

impact on the population and ecosystems and cause climate change. Biodiversity has already been lost as a result of human activity, and goods and services that are essential to human well-being may have been affected as well. Direct or indirect, climate change has had and will continue to have a negative effect on biodiversity. It is possible that these implications will have major negative effects on important ecosystem services, such as agricultural and animal production, disease regulation as well as the climate. One of the main effects of climate change is the modification of water resources and crop production. Systematic study on how climate change affects agriculture, forestry, animal husbandry and aquatic life must be strengthened immediately. Monitoring programmes that provide useful information for conservation and ecosystem-based management are needed to understand species' potential to adapt to climate change and also to the ecosystem characteristics that encourage resilience. As a country, we should employ all of our resources and efforts to reduce greenhouse gas emissions in order to combat global warming and natural disasters. Good government planning and policy execution will help mitigate biodiversity loss.

\section{References}

Allen, D.M., Mackie, D.C. and Wei, M.J.H.J. (2004). Groundwater and climate change: a sensitivity analysis for the Grand Forks aquifer, southern British Columbia, Canada. Hydrogeology Journal, 12(3): 270-290.

Asada, H. and Matsumoto, J. (2009). Effects of rainfall variation on rice production in the Ganges-Brahmaputra Basin. Climate Research, 38(3): 249-260.

Baker-Austin, C., Trinanes, J. A., Taylor, N.G., Hartnell, R., Siitonen, A. and Martinez-Urtaza, J. (2013). Emerging Vibrio risk at high latitudes in response to ocean warming. Nature Climate Change, 3(1): 73-77. 
Battisti, D.S. and Naylor, R.L. (2009). Historical warnings of future food insecurity with unprecedented seasonal heat. Science, 323(5911): 240-244.

Bellard, C., Bertelsmeier, C., Leadley, P., Thuiller, W. and Courchamp, F. (2012). Impacts of climate change on the future of biodiversity. Ecology Letters, 15(4): 365-377.

Bormpoudakis, D., Sueur, J. and Pantis, J.D. (2013). Spatial heterogeneity of ambient sound at the habitat type level: ecological implications and applications. Landscape Ecology, 28(3): 495-506.

Both, C., and Grant, T. (2012). Biological invasions and the acoustic niche: the effect of bullfrog calls on the acoustic signals of white-banded tree frogs. Biology Letters, 8(5): 714-716.

Brambilla, M., Pedrini, P., Rolando, A. and Chamberlain, D.E. (2016). Climate change will increase the potential conflict between skiing and high-elevation bird species in the Alps. Journal of Biogeography, 43(11): 2299-2309.

Carroll, C., Noss, R.F., Paquet, P.C. and Schumaker, N.H. (2004). Extinction debt of protected areas in developing landscapes. Conservation Biology, 18(4): 1110-1120.

Chevin, L.M., Lande, R. and Mace, G.M. (2010). Adaptation, plasticity, and extinction in a changing environment: towards a predictive theory. PLoS Biology, 8(4): e1000357.

Crick, H.Q. (2004). The impact of climate change on birds. Ibis, 146: 48-56.

Cudmore, T.J., Björklund, N., Carroll, A.L. and Staffan Lindgren, B. (2010). Climate change and range expansion of an aggressive bark beetle: evidence of higher beetle reproduction in naïve host tree populations. Journal of Applied Ecology, 47(5): 1036-1043.

Danovaro, R., Dell'Anno, A. and Pusceddu, A. (2004). Biodiversity response to climate change in a warm deep sea. Ecology Letters, 7(9): 821-828.

Dulvy, N.K., Rogers, S.I., Jennings, S., Stelzenmüller, V., Dye, S.R. and Skjoldal, H.R. (2008). Climate change and deepening of the North Sea fish assemblage: a biotic indicator of warming seas. Journal of Applied Ecology, 45(4): 1029-1039.

Eckhardt, K. and Ulbrich, U. (2003). Potential impacts of climate change on groundwater recharge and streamflow in a central European low mountain range. Journal of Hydrology, 284(1-4): 244-252.

Figueira, L., Tella, J.L., Camargo, U.M. and Ferraz, G. (2015). Autonomous sound monitoring shows higher use of Amazon old growth than secondary forest by parrots. Biological Conservation, 184: 27-35.

Goyal, R.K. (2004). Sensitivity of evapotranspiration to global warming: a case study of arid zone of Rajasthan (India). Agricultural Water Management, 69(1): 1-11.

Habibullah, M.S., Din, B.H. and Tan, S.H. (2019). Impact of Climate Change on the Number of Threatened Species: International Evidence. Review of Politics and Public Policy in Emerging Economies, 1(2): 61-78.

Harley, C.D., Randall Hughes, A., Hultgren, K.M., Miner, B.G., Sorte, C.J., Thornber, C.S. and Williams, S.L. (2006). The impacts of climate change in coastal marine systems. Ecology letters, 9(2): 228-241.

Hisano, M., Searle, E. B., and Chen, H. Y. (2018). Biodiversity as a solution to mitigate climate change impacts on the functioning of forest ecosystems. Biological Reviews, 93(1): 439-456.

Hui, D. (2013). Global climate change and biodiversity: Issues and future research. Journal of Biodiversity and Endangered Species, 1(1): 1-2.

Huntington, T. G. (2003). Climate warming could reduce runoff significantly in New England, USA. Agricultural and Forest Meteorology, 117(3-4): 193-201.

IFAW (2013) Climate Change and Animals_ How Climate Change Affects Life on Earth. International

IPCC (2001) Climate Change 2001: Impacts, Adaptation and Vulnerability: Contribution of Working Group II to the Third Assessment Report of the IPCC. Cambridge University Press, Cambridge, UK.

IPCC (2007) Summary for Policy-makers, Climate Change 2007: Mitigation. Contribution of Working Group III to the Fourth Assessment Report of the IPCC. Cambridge University Press, Cambridge, UK.

IPCC (2013). Climate Change 2013: The Physical Science Basics. Contribution of Working Group I to the Fifth Assessment Report of the Intergovernmental Panel on Climate Change. (T. F. Stocker, D. Qin, G.-K. Plattner, M. Tignor, S.K. Allen, J. Boschung P.M. Midgley, Eds.). Cambridge, United Kingdom and New York, NY, USA: Cambridge University Press. United Kingdom and New York, NY, USA: Cambridge University Press. 
IUCN (2000). Invasive Species Specialist Group, 2000. IUCN guidelines for the prevention of biodiversity loss caused by alien invasive species. Species Survival Commission

IUCN. (2010). 50 Years of Working for Protected Areas: A Brief History of IUCN World Commission on Protected Areas. Gland, Switzerland: IUCN.

Jackson, J. B. (2008). Ecological extinction and evolution in the brave new ocean. Proceedings of the National Academy of Sciences, 105(1): 11458-11465.

Kappelle, M., Van Vuuren, M.M. and Baas, P. (1999). Effects of climate change on biodiversity: a review and identification of key research issues. Biodiversity and Conservation, 8(10): 1383-1397.

Kimmel, E. (2009). Climate change adaptation and biodiversity: background report.

Krause, B., and Farina, A. (2016). Using ecoacoustic methods to survey the impacts of climate change on biodiversity. Biological Conservation, 195: 245-254.

Kumar, K.K., Rupa Kumar, K., Ashrit, R.G., Deshpande, N.R., and Hansen, J.W. (2004). Climate impacts on Indian agriculture. International Journal of Climatology: A Journal of the Royal Meteorological Society, 24(11): 1375-1393.

Lama, S., and Devkota, B. (2009). Vulnerability of mountain communities to climate change and adaptation strategies. Journal of Agriculture and Environment, 10: 76-83.

Leahy, S. (2007). “Environment: Between a Reef and a Hard Place.” NoticiasFinancieras

Lepetz, V., Massot, M., Schmeller, D.S., and Clobert, J. (2009). Biodiversity monitoring: some proposals to adequately study species' responses to climate change. Biodiversity and Conservation, 18(12): 3185-3203.

Lucas, T.C., Moorcroft, E.A., Freeman, R., Rowcliffe, J.M., and Jones, K.E. (2015). A generalised random encounter model for estimating animal density with remote sensor data. Methods in Ecology and Evolution, 6(5): 500-509.

Maracchi, G., Sirotenko, O. and Bindi, M. (2005). Impacts of present and future climate variability on agriculture and forestry in the temperate regions: Europe. Climatic Change, 70(1): 117-135.

Martens, P. and Rotmsans, J. (2005). Transitions in a Globalising World Futures, 37: 1133-1144.

Mooney, H., Larigauderie, A., Cesario, M., Elmquist, T., Hoegh-Guldberg, O., Lavorel, S. and Yahara, T. (2009). Biodiversity, climate change, and ecosystem services. Current Opinion in Environmental Sustainability, 1(1): 46-54.

Nunez, S., Arets, E., Alkemade, R., Verwer, C. and Leemans, R. (2019). Assessing the impacts of climate change on biodiversity: is below $2^{\circ} \mathrm{C}$ enough? Climatic Change, 154(3): 351-365.

Olesen, J.E., Carter, T.R., Diaz-Ambrona, C.H., Fronzek, S., Heidmann, T., Hickler, T. and Sykes, M.T. (2007). Uncertainties in projected impacts of climate change on European agriculture and terrestrial ecosystems based on scenarios from regional climate models. Climatic Change, 81(1): 123-143.

Omann, I., Stocker, A. and Jäger, J. (2009). Climate change as a threat to biodiversity: An application of the DPSIR approach. Ecological Economics, 69(1): 24-31.

Palita, S.K. (2016) Climate change and its impact on biodiversity.

Pearson, R.G., Phillips, S.J., Loranty, M.M., Beck, P.S., Damoulas, T., Knight, S.J. and Goetz, S.J. (2013). Shifts in Arctic vegetation and associated feedbacks under climate change. Nature climate change, 3(7): 673-677.

Piercy, J.J., Codling, E.A., Hill, A.J., Smith, D.J. and Simpson, S.D. (2014). Habitat quality affects sound production and likely distance of detection on coral reefs. Marine Ecology Progress Series, 516: 35-47.

Polovina, J.J. and Woodworth, P.A. (2012). Declines in phytoplankton cell size in the subtropical oceans estimated from satellite remotely-sensed temperature and chlorophyll, 1998-2007. Deep Sea Research Part II: Topical Studies in Oceanography, 77: 82-88.

Reid, H. (2006). Climate change and biodiversity in Europe. Conservation and Society, 84-101.

Risch, D., Castellote, M., Clark, C.W., Davis, G.E., Dugan, P.J., Hodge, L.E. and Van Parijs, S.M. (2014). Seasonal migrations of North Atlantic minke whales: novel insights from large-scale passive acoustic monitoring networks. Movement ecology, 2 (1): 1-17.

Roder, J., Bassler, C., Brandl, R., Dvorak, L., Floren, A., Gossner, M.M., Gruppe, A., Jarzabek-Muller, A., Vojtech, O., Wagner. C. and Muller, J. (2010). Arthropod species richness in the Norway Spruce (Piceaabies (L.) Karst.) canopy along an elevation gradient. Forest Ecology and Management, 259(8): 1513-1521. 
Rosales, J. (2008). Economic growth, climate change, biodiversity loss: distributive justice for the global north and south. Conservation Biology, 22(6): 1409-1417.

Sala, O.E., Chapin, F.S., Armesto, J.J., Berlow, E., Bloomfield, J., Dirzo, R. and Wall, D.H. (2000). Global biodiversity scenarios for the year 2100. Science, 287(5459): 1770-1774.

Sarkar, S. (2012). Impact of global warming on biodiversity. The Science Probe, 1(2): 22-33.

Sintayehu, D.W. (2018). Impact of climate change on biodiversity and associated key ecosystem services in Africa: a systematic review. Ecosystem health and sustainability, 4(9): 225-239.

Siraj, A.S., Santos-Vega, M., Bouma, M.J., Yadeta, D., Carrascal, D.R., and Pascual, M. (2014). Altitudinal changes in malaria incidence in highlands of Ethiopia and Colombia. Science, 343(6175): 1154-1158.

Sueur, J. and Farina, A. (2015). Ecoacoustics: the ecological investigation and interpretation of environmental sound. Biosemiotics, 8(3): 493-502.

Thomas, C. et al (2004). Extinction risk from climate change. Nature, 427: 145-148.

Thuiller, W. (2003). BIOMOD - optimizing predictions of species distributions and projecting potential future shifts under global change. Global Change Biology, 9: 1353-1362.

Thuiller, W., Lavorel, S., Arau'jo, M.B., Sykes, M.T. and Prentice, I.C. (2005). Climate change threats to plant diversity in Europe. Proceedings of the National Academy of Sciences of the United States of America, 102: 8245-8250.

Tuck, G., Glendining, M.J., Smith, P., House, J.I. and Wattenbach, M. (2006). The potential distribution of bioenergy crops in Europe under present and future climate. Biomass and Bioenergy, 30(3): 183-197.

Turan, C. and Gürlek, M. (2016). Climate change and biodiversity effects in Turkish Seas. Natural and Engineering Sciences, 1 (2): 15-24.

Van Vuuren, D.P., Sala, O.E. and Pereira, H.M. (2006). The future of vascular plant diversity under four global scenarios. Ecology and Society, 11: 1-19.

Welbergen, J.A., Klose, S.M., Markus, N. and Eby, P. (2008) Climate change and the effects of temperature extremes on Australian flying-foxes. Proceedings of the Royal Society B: Biological Sciences, 275(1633): 419-425.

Wernberg, T., Russell, B.D., Moore, P.J., Ling, S.D., Smale, D.A., Campbell, A. and Connell, S. D. (2011). Impacts of climate change in a global hotspot for temperate marine biodiversity and ocean warming. Journal of Experimental Marine Biology and Ecology, 400(1-2): 7-16.

Williams, S.E., Bolitho, E.E. and Fox, S. (2003). Climate change in Australian tropical rainforests: an impending environmental catastrophe. Proceedings of the Royal Society of London. Series B: Biological Sciences, 270(1527): 1887-1892.

Woodward, G., Perkins, D.M. and Brown, L.E. (2010). Climate change and freshwater ecosystems: impacts across multiple levels of organization. Philosophical Transactions of the Royal Society B: Biological Sciences, 365(1549): 2093-2106.

Cite this chapter as: Mahrukh and Kumar, R. (2021). Impact and assessment of climate change on biological diversity. In: Biological Diversity: Current Status and Conservation Policies, Volume 1, Eds. Kumar., V., Kumar, S., Kamboj, N., Payum, T., Kumar, P. and Kumari, S. pp. 108-122, https://doi.org/10.26832/aesa2021-bdcp-07 